\title{
Artifisial replenishment of the deep aquifers
}

\author{
Anatoly Hurynovich ${ }^{1, *}$, Valiantsin Ramanouski ${ }^{2}$ \\ ${ }^{1}$ Belostok Technical University, Engineering Systems in Environment Protection Department, 15- \\ 351, Vejska str., 45, Bialystok, Poland \\ ${ }^{2}$ Belarusian State Technologycal University, Industrial Ecology Department, 220006, Sverdlova str., \\ 13a, Belarus
}

\begin{abstract}
On the basis of the analysis, laboratory and pilot studies that have been conducted, schemes of artificial replenishment of deep aquifers are proposed. These schemes allow a groundwater recharge in order to water intake with generate electricity using the energy of the water flow and provide clear water, which serves to replenish underground water. Experimental section of this technological scheme was designed and built in the region of water intake in Brest (Belarus), on which were carried out hydrogeological surveys. Based on the above results, it was suggested to use the energy of the water flow in a water-inject well to convert it into electrical energy. A method for artificial groundwater recharge, which simultaneously allows groundwater recharge to the target groundwater without expending energy, generation of electricity using the power of the water flow and produces high quality water through the use of ozonation, which serves to replenish the groundwater was proposed. This is achieved through the use of hydraulic ram pump water-lifting devices, combined with electric generators, and a device for water purification such as an ozone generator. The proposed scheme and well design also allows the removal of iron and manganese from underground water and can be organized by two options, depending on the water source.
\end{abstract}

\section{Introduction}

Due to the extensive use of groundwater for water supply of cities the problems of groundwater depletion and maintain the quality of existing groundwater of existing water intakes for many countries today are very actually.

Therefore the artificial replenishment of existing groundwater is the most effective method to ensure their stable operation and, if necessary - increase productivity. Solving this problem requires research of hydrological characteristics of the corresponding surface water body source and water quality, determines the location and type of facilities for artificial groundwater replenishment.

With the increased demand for fresh water resulting from fast demographic growth, accelerated urbanization, economic and agricultural activity diversification, and the increase of per capita consumption, groundwater resources remain relatively low, compared to demand. It is becomes necessary to artificially create and store water reserves (artificial

\footnotetext{
* Corresponding author: a.gurinowicz@pb.bialystok.pl
} 
recharge of aquifers) of appropriate quality in the underground horizons, which, if necessary, could be used for water supply of cities, villages, as well as for agriculture and various industries.

The use of open basins, stream channels, and spray irrigation with present technology is possible with a typical secondary effluent, but recharge through wells requires wastewater of higher quality. Very slight turbidity and bacterial growths may lead to rapid clogging of recharge wells. The Artificial recharge of aquifers has a quite long history. China has a long history of managing aquifer recharge [1] since 1960s. The Italian project WARBO aims at facilitating the artificial recharge regulation in Italy by testing its application to mitigate the groundwater level drop in the Mereto site where the unused surplus surface water, which is usually lost during the winter-spring season, is utilized [2]. These area of research are very popular in different parts of the world, such as in Russia, Australia, Europe [2-4], Asia [1, 5-8], America [9, 10] etc. [11, 12].

Analysis of the Aquifer Storage Recovery systems in USA is shown [9] that water facility expansion capital costs are typically reduced by at least 50 percent. So, the role of artificial recharge can be expected to increase because of the growing water demand.

It should be mentioned, that artificial recharge of aquifers of the insufficient quality of pumped water may lead to increase the mobilisation of different pollutants in the unsaturated zone and reduce groundwater quality $[4,10]$.

Artificial groundwater recharge can be divided into 3 main types based on the hydrogeological and technical conditions:

- open replenishing in surface filtration from infiltration basins and channels;

- closed replenishing in filtering through wells;

- combined replenishment of groundwater, combining the two previous types.

Groundwater replenishment facilities by pre-water treatment, pumping and subsequent filtration of surface waters provide a high quality of water in water intake. Research of artificial replenishment processes and deferrization of groundwater in the aquifer using deep wells without filters were first carried out on existing wells in water intakes in Brest (Belarus).

Wells without filters in recent times become widespread both in Belarus and abroad, and their potential use in groundwater recharge schemes and deferrisation of groundwater in the aquifer have a great interest.

\section{Material and methods}

Figures and tables, as originals of good quality and well contrasted, are to be in their final form, ready for reproduction, pasted in the appropriate place in the text. Try to ensure that the size of the text in your figures is approximately the same size as the main text (10 point). Try to ensure that lines are no thinner than 0.25 point.

Water intakes of Brest exploit the water of Cenomanian aquifer having universal distribution at depths of 180-250 m and folded fine-grained sands average capacity of 25$30 \mathrm{~m}$. At the top are deposited quaternary and Paleogene-Neogene deposits represented by inequigranular sand, sandy loam and loam moraine, as well as marl-Cretaceous strata. The Cenomanian sands are underlain by Upper Jurassic deposits, composed of Oxford fractured limestones.

Water intake part of the well without filter is funnel (cavern), formed in sandy aquifer directly from the roofing overlapping layer waterproof breeds, which can be used in a single well for injection of oxidant and be pumping treated water. Such a scheme is shown in Fig. 1. 


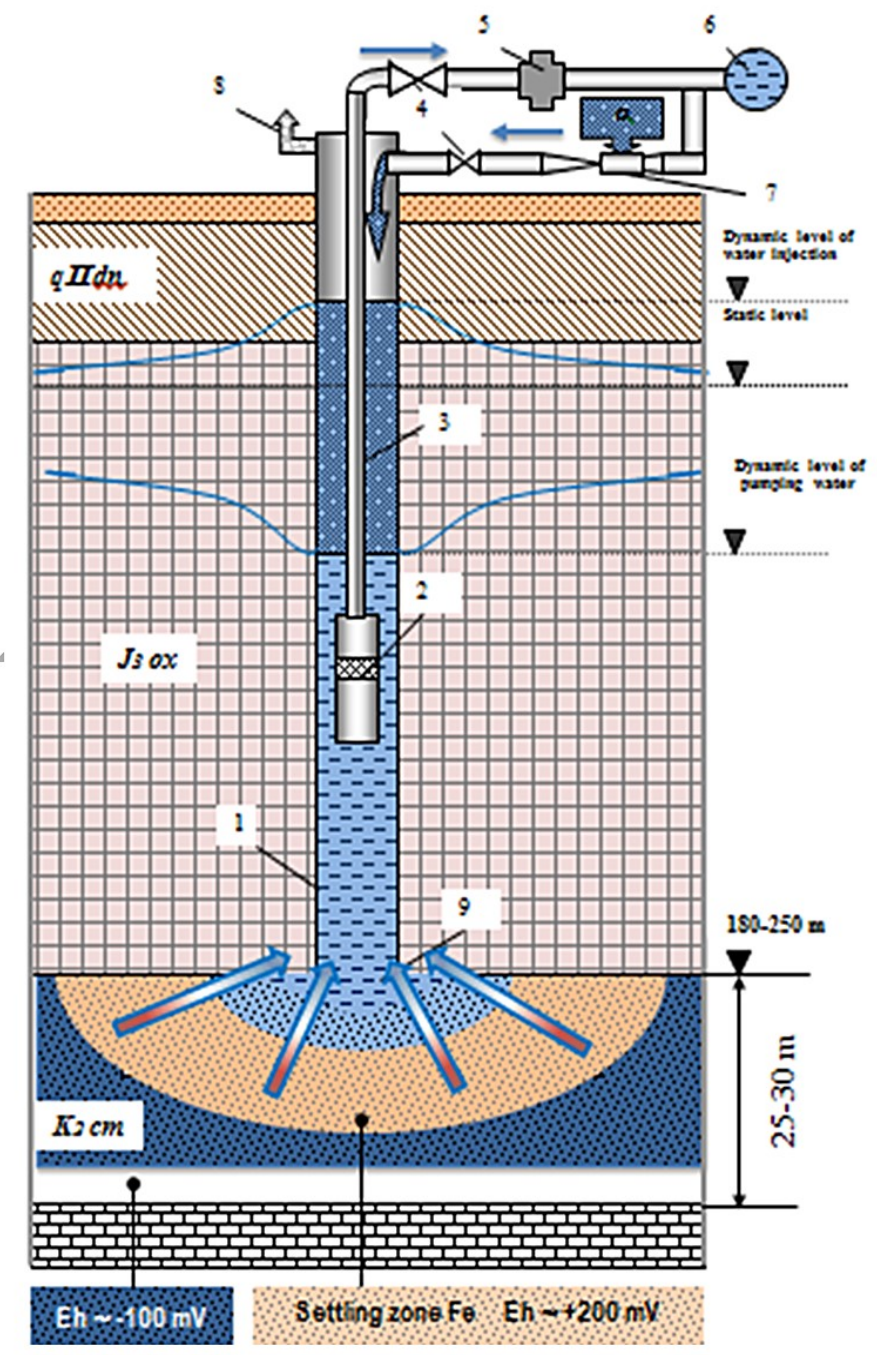

Fig. 1. Schematic diagram of the deferrization of water in the aquifer in the well without filter 1 - casing pipe; 2 - submersible pump; 3 - water-lifting pipe string; 4 - valve; 5 - water meter; 6 penstock; 7 - water-air ejector; 8 - air vent; 9 - cavern.

In this case, the oxidation zone and precipitation of iron form in a simplified form a hemisphere -3 , including the cavern -4 , the dimensions of which will depend on the volume of water injected into the formation with an oxidizing agent, and therefore can be set accurately. Inflow to a cavern of formation water, avoiding the oxidation zone, in fact, excluded. It should be noted that experience had shown good acceleration wells without a filter in the injection regime.

Injection into an aquifer only for clean aerated water is applied in order to prevent colmatation of wells with filters. For wells without filter, the colmatation of cavern surface is dangerous to a much lesser extent because easily eliminated by a simple washing - by increasing water intake.

Thus, the use of wells without filters in the schemes of deferrization in the aquifer can provide some significant advantages over the known circuits. 


\section{Results and disscutions}

At the first stage of the research examined the effectiveness of a new method deferrization in the conditions deep layers of the aquifer using of wells without filters, determined optimal technological regimes of groundwater purification process.

Chemically, the water of Cenomanian aquifer is bicarbonate-calcium, mineralization $400 \mathrm{mg} / \mathrm{l}$, alkalinity $-2.5-33.0 \mathrm{~m} \cdot \mathrm{Eq} / \mathrm{l}$, temperature $-\mathrm{t}=8-10^{\circ} \mathrm{C}$, total iron content $\mathrm{C}_{\mathrm{Fe}}=$ $2.4-2.6 \mathrm{mg} / \mathrm{l}$.

During the experiments was carried out a permanent control of the main chemical parameters of investigated water, changed various technological regimes, including the water consumption and injection-pumping volumes of water, downtime between the injection of water in wells and pumping, as well as the amount of oxygen supplied to the layer (dissolved or a water-air mixture).

The injection was performed in all cases by pressureless - free spout water injection under the level or above the water level in the well. When submitting into a well of airwater mixture, the bubble colmatation cavern was not observed, due to a high intrastratal pressure of $17.5-18.5 \mathrm{kgf} / \mathrm{cm}^{2}$, in which supports almost complete dissolution of air bubbles. In this case casing string with a diameter of more than $273 \mathrm{~mm}$ and low location of water shortage is becoming part of water treatment element, therein along with the processes of dissolution of air in water are also removed carbon dioxide $-\mathrm{CO}_{2}$ and hydrogen sulfide $-\mathrm{H}_{2} \mathrm{~S}$.

In total during research on the wells has been done 27 cycles of injection-pumping.

By injecting of water into the well without pre-aeration, the content of dissolved oxygen in the injected water was $-4.3-4.4 \mathrm{mg} / \mathrm{l}$. With aeration $-6-12 \mathrm{mg} / \mathrm{l}$.

Fig. 2 shows the results of determining the concentration of iron in the water pumped from the time of pumping for the first 6 cycles (Fig. 3.) in order to determine the kinetics parameters $\sigma_{\mathrm{Fe} 2}+$ and $\zeta$.

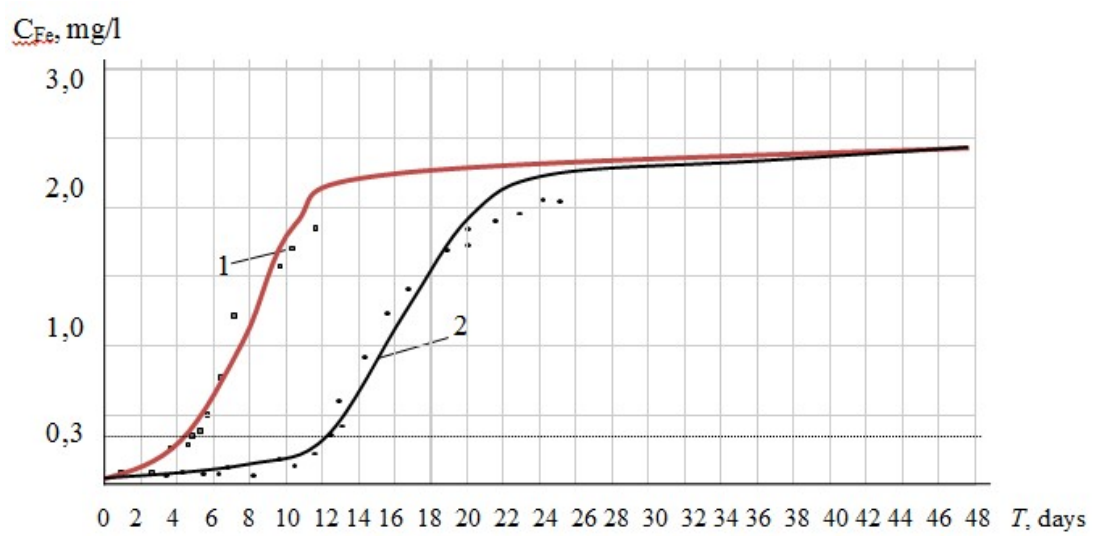

Fig. 2. Changes of iron total concentration during pumping out

1 - oxygen concentration in the injection water $\mathrm{CO}_{2}=6.0-7,0 \mathrm{mg} / \mathrm{l}$;

2 - oxygen concentration in the injection water $\mathrm{CO}_{2}=10.0-12.0 \mathrm{mg} / \mathrm{l}$.

Productivity of injection and pumping out were maintained constant within the range $\mathrm{Q}_{\mathrm{z}}$ $=\mathrm{Q}_{\mathrm{o}}=40-45 \mathrm{~m}^{3} / \mathrm{h}$, injection was carried out during the day. Ferrous iron in injected water was $2.4-2.5 \mathrm{mg} / \mathrm{l}$. The oxygen content in the injected water during the $1-3$ round of the experiment was 6-7 mg/l, at 4-6 round of the experiment was $10-12 \mathrm{mg} / \mathrm{l}$. After processing the data shown on fig. 2 the average values of the kinetics parameters amounted $\sigma_{\mathrm{Fe} 2}=0.04$ $(\mathrm{mg} \cdot 1 / \mathrm{h})^{-1}, \zeta=6,2 \mathrm{mg} / \mathrm{l}, \mathrm{C}_{\mathrm{O} 2}=12.2 \mathrm{mg} / \mathrm{l}$. 
With initial pumping out period (duration of each cycle was 30-35 days) from 2 to 5 days in the samples was observed a large number of air bubbles due to the degassing of the water as it rise and pressure reduction from $17-18 \mathrm{~kg} / \mathrm{cm}^{2}$ to atmospheric pressure, however, the content dissolved oxygen dropped sharply from the maximum value $7.12 \mathrm{mg} / \mathrm{l}$ to $0.2-0.3 \mathrm{mg} / \mathrm{l}$, gradually disappearing within $2-4$ days, for the same time completely disappears and $\mathrm{Fe}^{3+}$, which is formed by oxidation of $\mathrm{Fe}^{2+}$ for the movement of water from cavern to the sampling location.

Cleaning efficiency was determined by the ratio of selected water $-\mathrm{W}_{\mathrm{o}}$ in the moment of increasing the concentration of $\mathrm{Fe}^{2+}$ to the normative value $\left(\mathrm{C}_{\mathrm{d}}\right)$ to the volume of injected

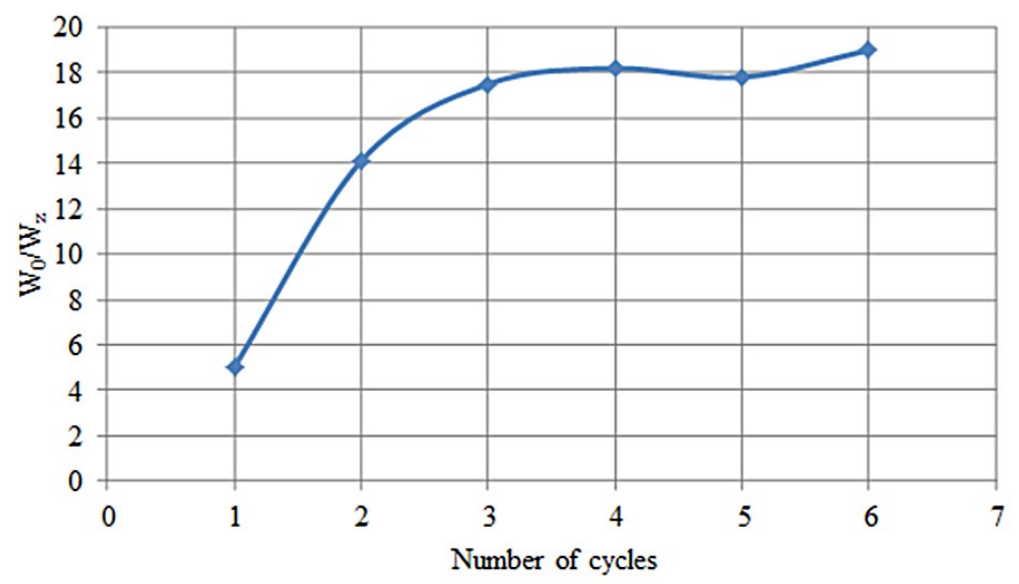

water $-\mathrm{W}_{\mathrm{z}}$ (Fig. 3).

Fig. 3. Efficiency of deferrization from number of cycles injection-pumping out.

\section{Conclusions}

Analysis of results showed that from cycle to cycle cause more reduction of $\mathrm{Fe}^{2+}$ in the pumped out water. In the initial period of pumping out concentration of iron approximately corresponds to the initial concentration in the water layer, mainly due to $\mathrm{Fe}^{3+}$, then decreases sharply and then approximately corresponds to $\mathrm{Fe}^{2+}$, gradually ramp up wherein the rise time is also increased from cycle to cycle.

Formation of a zone of oxidation and deposition during "charging" the formation of raw aerated water is much faster compared to the "charging" of pure water as this zone is additionally deposited iron contained in the injected water. In this case the colmatage of well cavern can be avoided by keeping the injection rate so that the movement of the injected water from the mixer to the formation is less than the start time of $\mathrm{Fe}^{2+}$ oxidation after aeration.

The effect of deferrization at short-term injection was also short-lived and unstable, due to the small size of the zone of oxidation and precipitation of iron.

To use of wells without filters for deferrization, and for artificial recharge were carried out experimental research in natural conditions in the process of water injection into the well without filters to determine the parameters of injectivity and the stability of slopes.

Injection was performed at a constant production rate for two modes of uptake and to a period of relative stabilization levels.

Before the experiment starts the well was switched off from the network to restore of the water level. Before and during the experiment carried out measurements of water levels 
in the injection well and in two observation wells. Pumping water from pressure pipe into the well was carried out during the first 23 hours with flow rates of $13.8 \mathrm{~m}^{3} / \mathrm{h}$, and then in the next 23 hours with a sharp increase in flow rate $-41.9 \mathrm{~m}^{3} / \mathrm{h}$. After the stop of the water injection during 13 hours measurements of water levels were taken.

In the first day of the experiment, the water level in the injection well has risen to 1.17 $\mathrm{m}$, and the specific pickup decreased from $35.1 \mathrm{~m}^{3} / \mathrm{h}$ to $12.5 \mathrm{~m}^{3} / \mathrm{h}$. By the end of the second day of the experiment, the water level in the well compared to the initial level increased to $3.4 \mathrm{~m}$. Specific injectivity decreased from $18.2 \mathrm{~m}^{3} / \mathrm{h}$ to $12.4 \mathrm{~m}^{3} / \mathrm{h}$. Water levels in observation wells to the end of the experiment increased by 0.89 and $0.36 \mathrm{~m}$ respectively. Thus, during the field experiment specific injectivity of well without filter was eventually equal to the specific yield of pumping out. In this case specific injectivity of first and second day of injection was the same.

The experimental results showed the possibility of injection at a rate equal to the flow rate for well.

Despite the good comparability of the calculated parameters with theoretical studies and characterization of technological regulations deferrization because of their comprehensiveness must be made empirically based on a thorough analysis of the results of preliminary researches.

One of the technological options of deferrization of water in the aquifer along with replenishment of groundwater reserves can be considered a method of pressure injection of infiltration river water into disposal wells, fitted on Cenomanian 7 and Oxford 8 interconnected aquifers (fig. 4). The approved scheme provides the supply of water from wells 3 for a discharge of infiltration water from the river basin 1 and 2 , the supply of infiltration water from wells 3 into reinjection well without filter 4 or to the well with a filter 5 and pumping out from wells without filter 6 .

Experimental section of this technological scheme was designed and built in the region of water intake in Brest (Belarus), on which were carried out hydrogeological surveys.

Based on the above results, it was suggested to use the energy of the water flow in a water-inject well to convert it into electrical energy. We have proposed a method for artificial groundwater recharge, which simultaneously allows groundwater recharge to the target groundwater without expending energy, generation of electricity using the power of the water flow and produces high quality water through the use of ozonation, which serves to replenish the groundwater. This is achieved through use of hydraulic ram pump waterlifting devices, combined with electric generators, and a device for water purification such as an ozone generator. The proposed scheme and well design also allows the removal of iron and manganese from underground water.

The method of artificial replenishment of groundwater with associated water intake, power generation and purification of water by ozonization operates as follows. When a surface water body (river, lake, reservoir, etc.) is located in close proximity to water intake wells, the first option of the method of artificial replenishment of groundwater with associated power generation and ozonation of water is applied. 


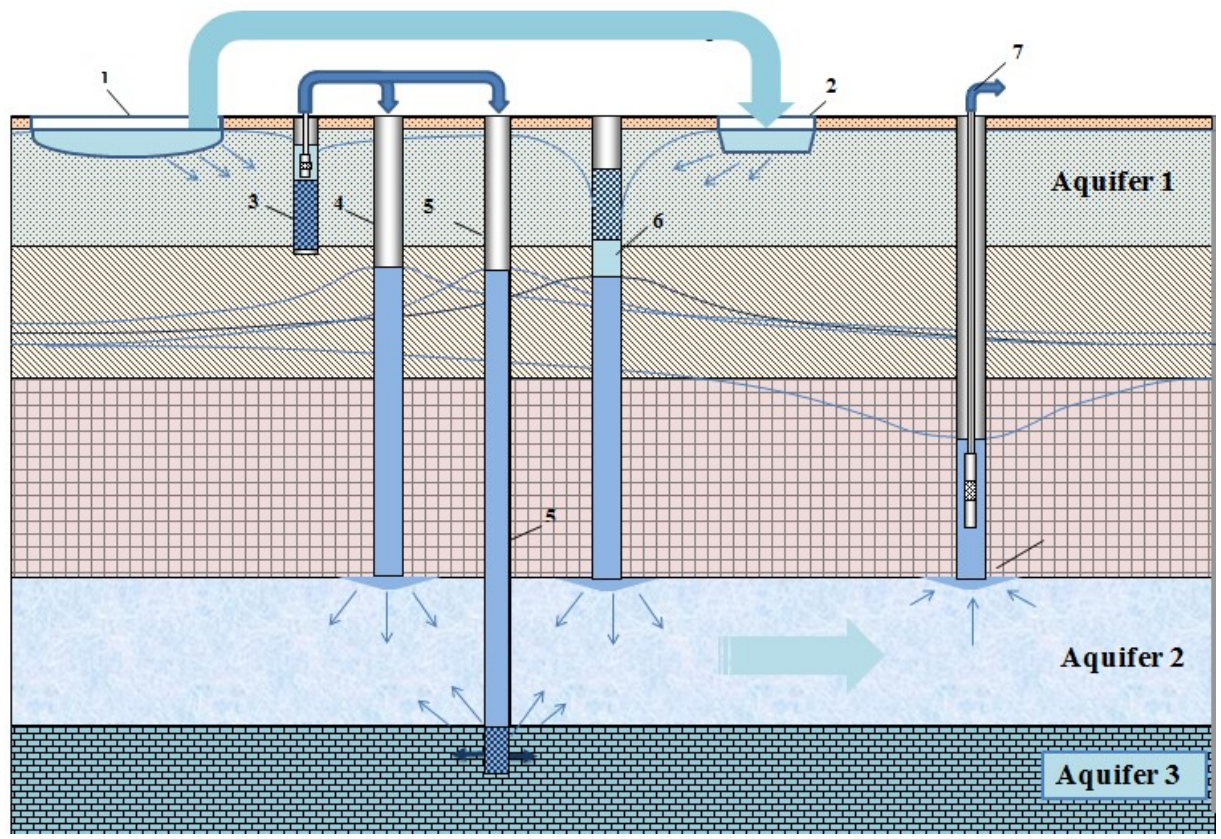

Fig. 4. Scheme of groundwater recharge with deferrization in aquifer 1 - riverbed 2 - infiltration pool, 3 - water wells of infiltration water, 4 - injection wells without filters, 5 - injection wells with filters; 6 - drainage and injection wells with filters; 7 - water wells without filters.

The water from the water body through the primary channel passes through the primary sluice to the surface water storage, then the water passes through the secondary channel through the secondary sluice to the tertiary channel. From the tertiary channel water is goes to the water supply pipe to the ozonizer, is saturated with ozone after passing through the ozonator. Then into the hydraulic ram pump, combined with the generator, after which water from the water body is comes to the second aquifer, saturating it with ozone, which cleans the water of this aquifer from microorganisms and oxidies substances. The hydraulic ram pump supplied with the generator feeds the ozone-saturated water from the water body to the water intake structure through the water supply pipe to the consumer. Electric power generated by the operation of hydraulic ram pump combined with the electric generator is supplied for household needs and for the ozonator by power cable.

If there is no available water intake facility in the immediate vicinity of the water intake wells, which uses groundwater, the reserves of which require replenishment a second variant of the method of artificial replenishment and intake of groundwater with associated electricity generation and ozonation of water can be proposed.

The water from the first aquifer, passing through the filter, enters into the water supply pipe, and further into the ozone generator where it is saturated with ozone. Then it is fed to the hydraulic ram pump, combined with an electric generator, after which water from the first aquifer is comes to the second aquifer, saturating it with ozone, which cleans the water of this aquifer from microorganisms and oxidizes substances. The hydraulic ram pump, combined with the generator, supplies the ozone-saturated water from the first aquifer to the water intake structure by means of a water supply pipe to the consumer. Electric power generated by the operation of hydraulic ram pump combined with an electric generator is supplied for household needs and for the ozone generator by the power cable.

The theoretical calculations showed that under favorable hydrological conditions, a single water-intaking well equipped with a hydraulic ram pump combined with an electric generator can produce more than $1 \mathrm{~kW} / \mathrm{h}$ of electricity, which can be used in various sectors 
of the economy, and under the most unfavorable hydrological conditions, the amount of electricity will be sufficient to ozonize the volume of water entering to accumulate in the underground horizons. Dissolved in water, ozone will not only disinfect groundwater, but also oxidize soluble iron compounds, transforming them into insoluble; neutralize chemically active substances, thereby increasing the quality of groundwater.

Thus, this method of artificial replenishment of groundwater with associated water intake, power generation and water purification by ozonization allows to combine artificial replenishment of underground waters with simultaneous generation of electricity, cleaning and supplying water to the consumer, by using as a water-lifting device a hydraulic ram pump combined with an electric generator, and as a device for water purification - ozone generator, fed by a part of the electricity generated by an electric generator.

\section{References}

1. W.-P. Wang, X.-B. Sun, Y. Xu International Conference on Challenges in Environmental Science and Computer Engineering, CESCE 2010, Wuhan; China; 6-7 March 2010, 2, 516-519 (2010)

2. G. Martellia, C. Granatia, G. Paieroa, P. Teatinib, A. Comerlatib, T. Carvalhoc, J. M. Carvalhoc, A. Affatatod, L. Baradellod, D. Nieto. 16th Conference on Water Distribution System Analysis, WDSA 2014. Procedia Engineering, 89, 1241-1248 (2014)

3. F. Wang, D. Halem, L. Ding, Y. Bai, K. Lekkerkerker-Teunissen, J. P. Hoek Water Res., 130, 88-97 (2018)

4. C. Levantesi, R. Mantia, C. Masciopinto, U. Böckelmann, M. N. Ayuso-Gabella, M. Salgot, V. Tandoi, E. Houtte, T. Wintgens, E. Grohmann Sci. Total Environ., 408, 4923-4930 (2010)

5. G. Zheng, J. R. Cao, X. S. Cheng, D. Hab, F. J. Wang J. Hydrol., 557, 868-877 (2018)

6. N. Phien-wej, P. H. Giao, P. Nutalaya Eng. Geol., 50, 187-201 (1998)

7. J. Wanga, Y. Wub, X. Zhang, Y. Liu, T. Yang, B. Feng J. Hydrol., 464-465, 328-343 (2012)

8. Y.-Q. Zhang, M.-G. Li, J.-H. Wang, J.-J. Chen, Y.-F. Zhu Eng. Geol., 228, 249-259 (2017)

9. R.D.G. Pyne Artificial Recharge of Ground Water (CH2M Hill Inc, United States, 1988)

10. J. Regnery, A. D. Wing, J. Kautz, J. E. Drewes Chemosphere, 154, 8-16 (2016)

11. O. Goren, I. Gavrieli, A. Burg, B. Lazar J. Hydrol., 400, 165-175 (2011)

12. C. Masciopinto J. Environ. Manage., 130, 306-312 (2013)

13. J. P. Bloomfield, R. J. Williams, D. C. Gooddy, J. N. Cape, P. Guha Sci. Total Environ., 369, 163-177 (2006) 